\title{
Gençlere Bilimi Anlatmak Üzerine Bir Deneyim: Uluslararası Gençlik ve Bilim Merkezi*
}

\section{An Experience on Teaching Science to Youth: International Youth and Science Center*}

\author{
Şuay Nilhan AÇIKALIN**, Şefika Şule ERÇETİN***, Nihan POTAS****, \\ Halime GÜNGÖR*****
}

\begin{abstract}
Öz: Çalışmanın amacı, gençlere bilimi anlatmak ve sevdirmek amacıyla kurulan Gençlik ve Spor Bakanlı̆̆ 1 tarafindan desteklenen Uluslararası Gençlik ve Bilim Merkezi’nin kuruluşunu, işleyişini, gerçekleştirdiği faaliyetleri, proje kapsamında gerçekleşen etkinliklerin etkililiğini anlatmaktır. Araştırma tarama modeliyle desenlenmiş olup, çoklu yöntem stratejisi benimsenmiştir. Çalışmaya 15-29 yaş arası 570 kız 588 erkek olmak üzere 1158 genç katılmıştır. Proje bitiminden 2017 yılı Haziran ayına kadar Uluslararası Bilim Derneği'nde yapılmış olan atölye çalışmalarına ise 15-29 yaş arası 420 kız 380 erkeğin oluşturduğu 800 genç katılmıştır. Çalışmanın bütününü ise $990 \mathrm{kız}$ ve 968 erkekten oluşan 1958 kişi meydana getirmiştir. 15-20, 20-25 ve 25-29 yaş aralığının oluşturduğu ve 3 grup halinde toplam 249 saat olarak bilim tarihi, Türk ve İslam Dünyasında bilim alimleri gibi 16 bilimsel etkinlik gerçekleştirilmiş projenin devamında da atölye çalışmaları şeklinde 172 saat çalışma yapılmıştır. Veri toplama aracı olarak araştırmacılar tarafindan geliştirilen "Gençlerin Gerçekleşmesi Planlanan Bilimsel Etkinliklere Yönelik Görüşleri Anketi", "Bilimsel Etkinlikleri Değerlendirme Anketi" ve "Bilimsel Etkinlikleri Değerlendirme Görüşme Formu" kullanılmıştır. Araştırma sonucunda gençlerin bilimsel etkinliklerden genel memnuniyet düzeyinin, eğitimcilerden memnuniyet düzeyinin ve fiziki olanaklar ve eğitim materyallerinden memnuniyet düzeyinin oldukça yüksek olduğu görülmüştür. Ayrıca bilimsel etkinlikleri gerçekleştiren eğitimcilerin anlattıkları konularda yeterli olduğunu, bilimsel etkinliklerin kariyerlerine ve kişisel gelişimlerine katkı sağladıklarını ifade etmişlerdir.
\end{abstract}

Anahtar Kelimeler: Eğitim, bilim, gençler, bilim merkezi

\begin{abstract}
The purpose of the study is to explain the establishment of the International Youth and Science Center, which is supported by the Ministry of Youth and Sports, which was established with the aim of explaining and ingratiating science to young people and to point out its existing activities and the activities carried out within the scope of the project. The research was designed in survey model and a multi-method strategy was adopted. 1158 young people aged 15-29, including 570 girls and 588 boys, participated in the study. From the end of the project until June of 2017, 800 young people, 420 girls and 380 boys between the ages of 15 and 29 participated in the workshops held in the International Science Association. In total, 1958 young people, 990 girls and 968 males, participated in the study. Sixteen scientific activities like science history, scientists in Turkish and Islamic world and 249 hours of work were carried out in the form of three workshops, 15-20, 20-25 and 25-29 years of age. In the continuation of the project, 172 hours of work were carried out in the form of workshop studies. "Views of Youths on Regarding the Scientific Activities Planned to Happen Questionnaire", Scientific Activities Evaluation

\footnotetext{
*Bu çalışma Eylül 2014-2015 döneminde Şuay Nilhan Açıkalın koordinatörlüğünde yürütülen 2014 Yılı Gençlik Projeleri Destek Programı I. Çağrı Döneminde TC Gençlik ve Spor Bakanlığı tarafından desteklenen "Uluslararası Gençlik ve Bilim Merkezi” Projesi kapsamında gerçekleştirilmiştir. Çalışmaya proje bittikten sonra Haziran 2017 tarihine kadar Uluslararası Bilim Derneği'nde devam edilmiştir. Çalışma Eylül 2014-Haziran 2017 dönemini kapsar. **Doktora Öğrencisi, Ortadoğu Teknik Üniversitesi, Sosyal Bilimler Enstitüsü, Uluslararası İlişkiler Doktora Program1, Ankara-Türkiye, ORCID: 0000-0002-5361-7667, e-posta: suaynilhan@ gmail.com

***Prof. Dr., Hacettepe Üniversitesi, Eğitim Fakültesi, Eğitim Bilimleri Bölümü, Ankara-Türkiye, ORCID: 00000002-7686-4863, e-posta: sefikasule@gmail.com

****Dr., Gazi Üniversitesi, İktisadi ve İdari Bilimler Fakültesi, Sağlik Yönetimi Bölümü, ORCID: 0000-0002-03933135, e-posta: nihan_potas@hotmail.com

*****Doktora Öğrencisi, Hacettepe Üniversitesi, Eğitim Bilimleri Enstitüsü, Eğitim Yönetimi Doktora Programı, ORCID: 0000-0002-3283-1250, e-posta: gungor.halime@gmail.com
} 
Questionnaire" and "Scientific Activities Evaluation Interview Form" developed by the researchers were used as data collection tools. As a result of the research, it was seen that the level of general satisfaction of young people with scientific activities, satisfaction level of trainer and satisfaction of physical possibilities and educational materials were quite high. They also stated that the trainers who performed the scientific activities were sufficient in the topics they told, contributing to the careers and personal development of the scientific activities.

Keywords: Education, science, youth, science center

\section{Giriş}

Türkiye İstatistik Kurumu'nun 2014 verilerine göre, Türkiye'de 15-29 yaş arasındaki gençler toplam nüfusun \%25'ini oluşturmaktadır. 15-19 yaş arasında 6.518.921, 20-24 yaş arasında 6.263.460, 25-29 yaş arasında 6.273.202 olmak üzere 15-29 yaş arası genç nüfusun 19.720.134'ü erkek, 9.335.49'ü kadın olmakla beraber toplamda 19.055.583 genç nüfus bulunmaktadır (www.tuik.gov.tr). Günümüzde ülkelerin var olan dünya düzeninde güçlü bir şekilde varlığını sürdürebilmeleri, kalkınmaları ve gelişmeleri genç nüfusun etkin bir biçimde bilimsel projelere ve araştırmalara katılımıyla mümkün olmaktadır. Bu anlamda, 2023-2071 hedeflerinde de yer aldığı gibi, nüfusunun \%25'inin gençlerin oluşturduğu bir ülke olarak Türkiye'de, gençlerin var olan ilgi ve yeteneklerinin doğrultusunda bilim alanlarında kendilerini geliştirmeleri, yetiştirmeleri ve bu alanda aktif rol oynaması öncelikli ve önemlidir. Ancak, yapılan son araştırmalar, bu konuda dikkatle ve özenle çok boyutlu çalışmalar gerçekleştirilmesi gerektiğini ortaya koymaktadır.

Nitekim Kaya, Afacan, Polat ve Urtekin (2013) tarafından yapılan çalışmada bilim insanlarının kişisel ve mesleki özellikleri hakkındaki öğrenci görüşlerinin yeterince derin olmadığı, öğrencilerin bilimsel bilgi ve bilim insanı ile ilgili sorulara daha çok kulaktan dolma ya da yüzeysel cevaplar verdikleri bulgulanmıştır. Buluş Kırıkkaya (2010) tarafından yapılan çalışmada ise öğrencilerin az da olsa bilime ve bilim insanlarına ilgi ve yöneliminin olduğu ancak öğrencilerin bilimsel çalışmalara ve bilim insanlarına duyulan ilgi ve yöneliminde fen dersleri ve öğretmenlerinin etkili olmadığı belirlenmiştir. Kaya ve Yılmaz (2016) tarafından yapılan araştırmada öğrencilerin akademik başarılarının artırılması ve bilimsel süreç becerilerinin gelişimi için açık sorgulamaya dayalı öğrenmeye uygun etkinliklerin fen sınıflarında kullanılması gerektiği vurgulanmıştır.

TÜBITTAK tarafindan 2005 yılında 47 ilde, 15-24 yaş arası 1033 gence çeşitli sorular sorularak yapılan bilim okuryazarlığı araştırmasında gençlerin, "bilim" dendiğinde gözlerinde canlanan imgenin ciddi, asık suratlı, orta yaşlı bir erkek figürü olduğu sonucuna ulaşılmıştır. Böyle bir erkek figürünün olması, günümüzde bilim adamı yerine bilim insanı kelimesi kullanılmaya başlanmasına rağmen algıda cinsiyete yönelik ayrımın sürdüğü düşüncesini tartışmaya açmaktadır. Gençlerin bilimi yakından tanımaları, her gencin bilimsel okuryazar olabilmesi, bilime yönelik algılarının değişmesi ve bu algının modern çağın gereklerine uyumlanması hususunda ise bilim merkezleri anahtar rol oynamaktadır. Gençlere bilimin sevdirilmesi ve bilime olan ilgilerinin arttırılmasında kullanılabilecek en etkili yerlerden biri de bilim merkezleridir.

Bu konuda Falk, Needham, Dierking ve Prendergast (2014) tarafından yapılan çalışma ise gençlerin bilimi bilim merkezlerinde tanımaları konusuna 1şık tutmaktadır. 13 ülkede bulunan 17 bilim merkezinde bilim ve teknoloji okuryazarlığ 1 ve bilim merkezleri arasındaki ilişkinin ölçüldüğü çalışmada ise bilim merkezlerine devam eden bireylerin bilim ve teknoloji okuryazarlığının normal vatandaşlara göre daha iyi düzeyde olduğu sonucuna ulaşılmıştır (Falk ve diğerleri, 2014).

Son dönemlerde Gençlik ve Spor Bakanlığı, Kalkınma Bakanlığı, TUBİTAK, YÖK, sivil toplum kuruluşları gençleri, gençlere yönelik hazırlanan projeleri ve yapılan bilimsel araştırmaları, bilim insanlarını burslarla ve hibe programları ile desteklemektedir. Verilen desteğin somut örneklerinden biri de Uluslararası Gençlik ve Bilim Merkezi Projesi'dir.

Gençlere bilimi sevdirmek, bilimin eğlenceli ve öğretici yanını göstermek için en başta ailelere, okullara, öğretmenlere ve bilim merkezlerine önemli görevler düşmektedir. Bu gerçeği 
fark etmis ve bilim merkezlerini kurarak gençlerin hizmetine sunmuș ülkeler arasında Kanada, $\mathrm{ABD}$, İngiltere ve Japonya vardır. Gençlerimiz bugünün itici gücü, yarının ise güvencesidir. Gençlik, milletlerin sahip olduğu en büyük hazinedir ve ülkemiz bu hazineye diğer ülkelere kıyasla fazlasıyla sahiptir. Gençlere, bilimsel düşünce sistematiği ve bilimsel tutum kazandırmak; bilimsel okur-yazar bireyin özelliklerini açılayabilmek ve kazandırabilmek; gençlerin, dışarıda kötü alışkanlıklara enerji harcamaları yerine, bilime enerji harcamaları ve okullarından arta kalan zamanlarda bilimsel ve eğlenceli bir ortamda bulunmalarını; bilimsel anlamda kendi gelişimine katkıda bulunarak topluma uyumlu olmalarını sağlamak, sorunların çözümüne yardımcı olmak, rehberlik ve danışmanlık yapmak, ulusal ve uluslararası düzeyde yapılacak bilimsel çalışmalara ve gençlik organizasyonlarına, diğer gençlik ve bilim kuruluşlarıyla ortaklık kurarak katkı sağlamak, buralardaki önde gelen bilim insanlarıyla gençleri buluşturmak, bilgilendirmek ve gençlere rol model oluşturmalarını sağlamak onların gelecekte uluslararası düzeyde ülkemizi en iyi şekilde temsil etmeleri bakımından son derece önemli ve önceliklidir.

\section{Bilim Merkezleri}

Bilim merkezleri, müzeler ve diğer resmi olmayan bilim kurumları, okullarda bulunmayan birçok benzersiz özelliğe ve araçlara sahip oldukları için, pek çok uygulamalı bilim eğitimi deneyimi yaşamak adına ideal (Eberle, 2011) olmasının yanında bilim merkezlerinin, gençlerin bilim ve teknoloji alanında yükseköğrenimi seçmelerini teşvik etmede önemli bir kaynak olduğu söylenebilir (Fors, 2006). Bilim merkezi düşüncesinin temellerine bakıldığında aslında son yüzyıla ait bir düşünce olmadığı görülmektedir.

Avrupa'da Bilim merkezi düşüncesinin deneylerin doğayı keşfetmenin doğru yolu olduğunu iddia eden İngiliz filozof Francis Bacon'un (1561-1626) fikirlerinden üretilmiş olduğu ve Bacon'un "keşifler için müze" önerisiyle kurulmuş olan ilk bilim merkezinin ise Paris'teki Le Conservatoire National des Arts et Métiers olduğu söylenebilir (Fors, 2006). Avrupa henüz ortaçağı yaşarken bilim anlamında altın çağını yaşayan Türk ve İslam Dünya'sına bakıldığında bilim merkezi düşüncesinin çok daha önceki dönemlere dayandığı görülebilir.

Bilim Tarihi, Türklerin de içinde yer aldığı İslâm Dünyasının Ortaçağda, Batı Avrupa karanlık bir dönem yaşarken parlak ve yüksek bir uygarlığa sahip olduğunu göstermiş, 750-1100 yılları arasındaki dönemi Câbir, Hârezmî, Râzi, Abû'l Vefa, Beyrûnî, İbn Sînâ, İbn Heysem, Ömer Hayyam gibi Türk-İslâm bilim adamlarıyla simgeleştirmiştir (Dosay, 1992). Aynı dönemde, Türk İslam bilim tarihinde en önemli bilim merkezlerinden biri olan Bağdat, 'Urfa ve Nusaybin, Cundisapur, Harran, Antakya, İskenderiye ve Atina okullarının temel düşünsel mirasını bünyesinde toplamış ve seçkin bir bilim ve felsefe merkezi (Aydın, 2002) iken 13. yüzyılda ise Tebriz önemli bir bilim merkezine dönüşmüştür (2007).

Günümüze gelindiğinde ise araştırmalar, bilim merkezleri hareketinde, 20. yüzyılın başlarında kurulan Londra Bilim Müzesi (1928), Münih’te 1925 yılında açılan Alman Müzesi, Chicago'da 1933 yılında açılan Bilim ve Sanayi Müzesi gibi bilim merkezlerinin temeli olan büyük bilim ve sanayi müzelerinin kuruluşunun bilimsel eğitim reformu adına son derece önemli olduğunu göstermektedir (Beetlestone, Johnson, Quin ve White, 1998; Fernandes Sousa, 2017).

Şekil 1'e göre bilim merkezlerinin finansman, personel ve gönüllüler ile faaliyetleri yürüten kurumlar olarak kişisel, toplumsal, politik ve ekonomik olmak üzere dört düzeyde etkileri vardır. 

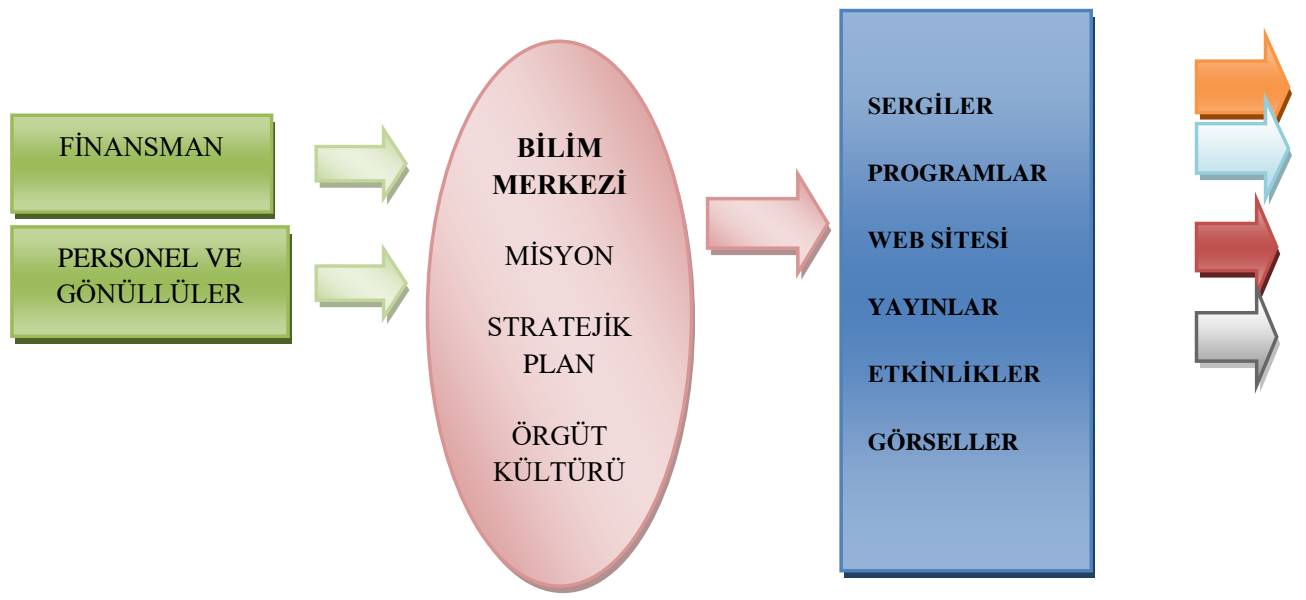

KIŞSiSEL ETKI

TOPLUMSAL ETKİ

POLITIK

ETKİ

EKONOMIK ETKİ

Girdiler

Şekil 1. Bilim Merkezi Etkisi Modeli

Çıktılar

Etkiler

Kaynak. Garnett ve Ghislaberti (2001).

Garnett ve Ghislaberti (2001) 180 bilim merkezinin raporlarını inceleyerek yaptıkları çalışmada raporların \%87'sinde merkezlerin devam edenlere etkilerinin kişisel olduğu, \%9'unda toplumsal ve \%4'ünde ekonomik olduğunu bulgulamışlardır. Kişisel etkinin \%54'ü bilimsel öğrenme, \%18'i bilime olan tutumda değişiklik, \%14'ü eğlence, \%7'si kariyer seçiminde destek alma, \%7'si ise diğer olarak açıklanmıştır. Bu bağlamda, bilim merkezlerinin "öğrenenler" konusuna odaklanması ve öğrenenleri öz-yönelimli, özgün, sosyal ve sürükleyici deneyimlere dâhil etme potansiyeli, özellikle uygun teknoloji ile geliştirilip genişletilebiliyorsa, bilim merkezlerinin varlığı ve varlığını sürdürebilmesi önemlidir (Ucko, 2013).

Gençlik Bilim Merkezleri sadece Ankara ili içerisinde değil, Türkiye genelinde bir nevi müze gibi olup gençlerin belirli saat aralıklarında dolaşımına açıktır. Ancak, gençlerin birkaç tematik etkinlik dışında interaktif bilimin farklı dallarında öğrenme süreci gerçekleştirecekleri, bizzat yaparak, yaşayarak öğrenecekleri, bilimsel süreçlerin içine katılacakları bir ortam, bir kurum, bir kuruluş ülkemizde bulunmamaktadır. Ülkemizde hemen hemen her il merkezinde açılan bilim ve sanat merkezleri ise merkeze seçilerek kabul edilen üstün zekâlı, resim ve müzik alanlarında üstün yetenekli olan çocuklara gençlere hizmet vermektedir. Bu bağlamda, sadece belirli bir kesime değil, kapsayıcı ve çoğulcu bir anlayış ile gençlere bilim hizmeti sunacak bir Uluslararası Gençlik ve Bilim Merkezi kurulması ülkemize büyük bir hizmettir.

\section{Uluslararası Bilim Derneği}

Bilim alanında gençlere hizmet eden en önemli sivil toplum kuruluşlarından biri olan Uluslararası Bilim Derneği'nin misyonu "çok daha iyi bir gelecek için bilimi ve bilgiyi eş zamanlı, çok boyutlu ve etik değerleri benimseyerek uyumlaştırma gücünde ve kararlığında olanları bir araya getirmek ve desteklemek"tir. Merkezi Ankara'da olan Uluslar arası Bilim Derneği ulusal ve uluslararası, bireysel ve kurumsal düzeyde, uluslararası ilişkiler, siyaset, kamu yönetimi, işletme, iktisat, eğitim, sosyal psikoloji gibi sosyal bilimlerin, istatistik, fizik matematik, kaos, karmaşıklık gibi fen, tıp bilimlerinin her alanında teknoloji, araştırma, geliştirme, uygulamaya dönüştürme faaliyetleri ile sosyal, ekonomik, kültürel, tarihi ve bilimsel her türlü iletişim, etkileşim ve işbirliğini gerçekleştirmek, kurum ve kuruluşlar ile ilgili olarak; etik, sosyal, ekonomik ve bilimsellik boyutları içeren çeşitli kriterler oluşturmak, bu kriterler açısından kurum, kuruluşları değerlendirmek, derecelendirmek ve bunları yayınlamak amacı ile kurulmuştur.

Derneğin kuruluş amacına uygun faaliyetlerin etkinleştirilmesi ve geliştirilmesi için sosyal ve fen bilimlerinin her alanında disiplinler arası yaklaşımla bilimsel ve uygulamaya 
dönük çok sayıda araştırma, sempozyum, kurs, kongre, seminer, konferans, çalıştay, panel, hizmet içi eğitim çalışmaları, proje gerçekleştirilmiş ve bu sayede derneğin amacı kapsamında uluslar arası işbirliğini geliştirilmesi hedeflenmiştir. Ayrıca Uluslararası Bilim Derneği'nde gençler, gençlik çalışanları, kadınlar, kız çocukları ve dezavantajlılar konusunda kurs, seminer, konferans ve panel gibi eğitim çalışmaları, bütün bunları içeren ulusal ve uluslararası proje çalışmaları düzenlenmekte; üniversitelerde lisans, yüksek lisans, doktora ve doktora sonrası düzeyde eğitim ve yönetimde gençler, kadınlar, kız çocukları ve dezavantajlılar konusunda politika analizleri ve stratejik araştırmalarla ilgili ders ve seminer verilmekte, ilgili alanlarda çalışan akademisyenlerin bu konulara yönelmesini özendirici eğitsel çalışmalar yapılmaktadır.

\section{Uluslararası Gençlik ve Bilim Merkezi}

Uluslararası Bilim Derneği öncülügünde yürütülen Uluslararası Gençlik ve Bilim Merkezi'nin açılması ve yürütülmesine ilişkin proje ülkemizde alanında en iyi örneklerden biri olmuştur. Projede bilim ve teknolojiye hâkim, teknolojiyi bilinçli kullanan ve yeni teknolojiler üretebilen, teknolojik ve bilimsel gelişmeleri toplumsal ve ekonomik faydaya dönüştürme yeteneği kazanmış bir gençlik ile birlikte refah toplumunun tesisi ve temini hususuna hizmet etmek amaçlanmıştır. Özel amaçlar ise; Türkiye'de ve Ankara'da 15-29 yaş arası gençlere bilimin farklı alanlarının sevdirilmesi, bilimsel projelerde aktif rol verilmesi ve bilimsel bilginin yapısını anlayan, uygun bilimsel kavramları, ilkeleri, kanun ve teorileri, evreniyle iletişim içindeyken kullanmayı öğretmek olarak belirlenmiştir. Bu amaçla öncelikle Uluslararası Bilim Derneği bünyesinde Uluslararası Gençlik ve Bilim Merkezi'nin kuruluşu gerçekleştirilmiştir.

Projede öncelikle uygulamanın yapılacağı yer kiralanmıştır. Seçilen yerin her kademedeki eğitim kurumlarına yakınlığı ve ulaşım kolaylığı düşünülmüştür. Yer kiralandıktan sonra mekân içi düzenlemeler yapılmıştır. Proje ofisinin oluşturulması çalışmaları yapılmış ve projenin amaçlarının gerçekleştirilmesine uygun ortam hazırlanmış, merkez çalışmalar için uygun hale getirilmiştir. Ofis için gerekli olan bazı ofis malzemeleri ve sarf malzemelerinin alımı mekânın uygunluğu ve kişi sayısını maksimize etme amacı düşünülerek gerçekleştirilmiştir. Satın alması gerçekleşen ekipman ve malzemeler: masaüstü bilgisayar, dizüstü bilgisayar, yazıc1, tarayıcı, fotokopi makinesi, televizyon, ofis mobilyası takımı ve koltuğu, çalışma masalarıdır. Ayrıca merkeze kameralı güvenlik sistemi kurulumu gerçekleşmiştir.

Uluslararası Gençlik ve Bilim Merkezi'nin evrensel ve modern seviyesinin yüksek bir seviyede olması için, Dünya'daki benzer uygulamalar olan merkezlere çalı̧̧ma ziyaretlerinin gerçekleştirilmesi planlanmıştır. Çalışmaları yerinde incelemek, bilgi ve örnek uygulamaları almak için Konya ilinde bulunan Konya Bilim Merkezi'ne 5 kişilik bir heyet ile 1 günlük çalışma ziyareti gerçekleştirilmiştir.

Uluslararası Gençlik ve Bilim Merkezi ülkemizde bir sivil toplum kuruluşu tarafından kurulan ve yürütülen ilk gençlik merkezi olma özelliğini taşıdığından alanında önder ve model olması bakımından da önem taşımaktadır. Merkezin fiziki altyapı hazırlandıktan sonra merkezin ve projenin tanıtımı ve çalışmaların duyurusu yapılmış ve gençlerin merkezi ziyaretleri başlamış, gençlere bilimi sevdirmek amacıyla bilimsel etkinlikler yapılmış ve yapılan etkinlikler çerçevesinde çalışmaların etkinliği ölçümlenmiş ve analiz edilmiştir.

Proje Eylül 2014-Eylül 2015 tarih aralığında gerçekleştirilmiş̧ir. Proje tamamlandıktan sonra Uluslararası Bilim Derneği'nin kendi imkânları çerçevesinde projeye 2017 yılı Haziran ayına kadar devam edilmiş, bu kapsamda gençlere atölye çalışmaları şeklinde bilimi sevdirme programı uygulanmış, Türk İslam bilim insanlarının tanıtımı ve bilime katkıları öğretilmeye çalışılmıştır.

Çalışmanın amacı, gençlere bilimi anlatmak ve sevdirmek amacıyla kurulan Gençlik ve Spor Bakanlığı tarafından desteklenen Uluslararası Gençlik ve Bilim Merkezi'nin kuruluşunu, işleyişini, gerçekleştirdiği faaliyetleri, proje kapsamında gerçekleşen etkinliklerin etkililiğini anlatmaktır. 


\section{Yöntem}

Araştırma tarama modelinde desenlenmiş olup, çoklu yöntem stratejisi benimsenmiştir. Öncelikle araştırmada gençlere Gençlerin Gerçekleşmesi Planlanan Bilimsel Etkinliklere Yönelik Görüşleri Anketi uygulanmış, anket sonuçları değerlendirilerek yapılacak faaliyetlere karar verilmiş, 15-29 yaş arası gençlere 15-20, 20-25 ve 25-29 yaş olmak üzere 3 grup halinde ve toplam 249 saat olarak 16 bilimsel etkinlik ve projenin devamında atölye çalışmaları şeklinde 172 saat çalışma alanında uzman eğitimciler tarafından gerçekleştirilmiştir. Yapılan Bilimsel Etkinlikleri Değerlendirme Anketi ve Bilimsel Etkinlikleri Değerlendirme Görüşme Formu ile faaliyetlerin sonunda gençlerin faaliyetlere yönelik görüşleri alınmış ve analiz edilmiştir.

\section{Evren ve örneklem}

Ankara'da toplamda 1.245.708 15-29 yaş arası genç birey çalışma evrenini oluşturmaktadır. Örneklem Rastgele Örnekleme yöntemi ile belirlenmiştir. \%95 güvenle oran tahmininin \pm 0.03 sınırları dâhilinde olabilmesi için gerekli örneklem hacmi $\mathrm{z}=1.96 \approx 2, \mathrm{~d}=0.03, \mathrm{p}=0.5$ alındığında,

$n_{0}=\frac{z^{2} * P * Q}{d^{2}}=\frac{4 *\left(\frac{1}{2}\right) *\left(\frac{1}{2}\right)}{\left(\frac{3}{100}\right)^{2}}=\frac{10000}{9} \cong 1112$

örneklem gerekmektedir. Çalışmalara projenin başlangıcından bittiği 2015 Eylül tarihine kadar 15-29 yaş arası 570 kız 588 erkek olmak üzere 1158 genç katılmıştır. Gençlerin Gerçekleşmesi Planlanan Bilimsel Etkinliklere Yönelik Görüssleri, Bilimsel Etkinlikleri Değerlendirme Anketi ve Görüşme Formu 1158 gençten toplanmış. Proje bitiminden 2015 Eylül tarihinden 2017 yılı Haziran ayına kadar Uluslararası Bilim Derneği'nde yapılmış olan atölye çalışmalarına 15-29 yaş aras 420 kız, 380 erkek olmak üzere 800 genç katılmıştır. Atölye çalışmalarının sonunda 800 gence ise Bilimsel Etkinlikleri Değerlendirme Anketi uygulanmıştır. Toplamda çalışmaya 990 kız, 968 erkek olmak üzere 1958 genç katılmıştır.

\section{Veri toplama araçları}

Uluslararası Gençlik Bilim Merkezi kurulduktan sonra gönüllü gençlerle yapılacak faaliyetlerin planlanmasında ve faaliyetlerin verimliliğinin ölçülmesinde tarama araştırmaları veri toplama tekniklerinden anket kullanılmıştır. Veri toplama aracı olarak proje kapsamında geliştirilen Açıkalın, Erçetin, Potas, Güngör tarafından geliştirilen "Gençlerin Gerçekleşmesi Planlanan Bilimsel Etkinliklere Yönelik Görüşleri Anketi", "Bilimsel Etkinlikleri Değerlendirme Anketi" ve "Bilimsel Etkinlikleri Değerlendirme Görüşme Formu" kullanılmıştır.

\section{Gençlerin Gerçekleşmesi Planlanan Bilimsel Etkinliklere Yönelik Görüşleri Anketi}

Gençlerin Gerçekleşmesi Planlanan Bilimsel Etkinliklere Yönelik Görüşleri Anketi ilgili alanyazın taraması yapılarak hazırlanan sorulardan oluşmaktadır. Anket hazırlandıktan sonra uzman görüşü alınarak kapsam geçerliliği gözden geçirilmiştir. Ankette yapılması planlanan etkinliklerin içeriğine yönelik 50 konu seçeneği bulunmaktadır. Başka tercihin var mı seçeneği ile toplam 51 konu seçeneğinden gençlerin ilgi duydukları ve merak ettikleri konuları seçmeleri istenmiştir. Anket projeye katılan 1158 gence uygulanmıştır.

\section{Bilimsel Etkinlikleri Değerlendirme Anketi}

Bilimsel Etkinlikleri Değerlendirme Anketi'nde proje kapsamında gerçekleştirilen 17 etkinliğin katılımcılarına eğitimden memnuniyeti, eğitim materyallerinden memnuniyeti, eğitim ortamından memnuniyeti, etkinlikten memnuniyeti olmak üzere 4 alanda hazırlanmış 12 sorudan oluşmaktadır. Anket hazırlandıktan sonra uzman görüşü alınarak kapsam geçerliliği gözden geçirilmiştir. Ankette 5li Likert tipi derecelendirme kullanılmıştır. Anket her etkinliğin ardından etkinliğe katılan gençlere uygulanmış ve her etkinlik için ayrı değerlendirme 
yapılmıştır. Anket proje sürecinde 158 ve projenin devamında 800 olmak üzere 1958 gence uygulanmıştır.

\section{Bilimsel Etkinlikleri Değerlendirme Görüşme Formu}

Bilimsel Etkinlikleri Değerlendirme Görüşme Formu oluşturulurken ilgili alanyazın taraması yapıldıktan sonra uzman görüşü alınarak kapsam geçerliliği gözden geçirilmiştir. Görüşme Formu'nda katılımcılar yöneltilen sorular şöyledir; Katıldığınız faaliyeti gerçekleştiği ortamın fiziki olanakları açısından değerlendirir misiniz? Katıldığınız faaliyeti eğitim materyallerinin yeterliliği açısından değerlendirir misiniz? Katıldığınız faaliyeti gerçekleştiren eğitim uzmanını hakkında görüşleriniz nelerdir? Uluslararası Bilim Merkezi projesi hakkında görüşleriniz nelerdir? Uluslararası Bilim Merkezi projesinin yaşamınıza katkıları oldu mu? Hangi açılardan? Olmadıysa sebeplerini açıklar mısınız? Görüşme formu projeye katılan 1158 gençten 15 genç ile görüşmeler yapılmış, projenin devamında ise atölye çalışmalarına ilişkin 22 genç ile görüşmeler yapılmıştır.

\section{Verilerin analizi}

Araştırmanın Ankara'da yaşayan ve Uluslararası Gençlik ve Bilim Merkezi'ne devam eden 1529 yaş arası gençlerin gerçekleşmesi planlanan bilimsel etkinliklere yönelik görüşlerinin belirlenmesinde betimsel istatistik yöntemleri kullanılmıştır. Gençlerin katıldıkları bilimsel etkinliklere yönelik değerlendirmelerine ilişkin görüşlerine yönelik veriler ise bireysel görüşmeler yapılarak toplanmıştır, çözümlenmesi ve yorumlanmasında ise içerik analizi yapılmıştır.

\section{Bulgular}

Gençlerin gerçekleşmesi planlanan bilimsel etkinliklere yönelik görüşlerine ilişkin bulgular

Gençlerin Gerçekleşmesi Planlanan Bilimsel Etkinliklere Yönelik Görüşleri Anketinin sonuçlarına göre, hedef kitlesindeki gençlerin tercih ettiği bilimsel eğitimler Tablo 1'de gösterilmiştir. Katılımcılar 50 konu başlı̆̆ından 16 konu başlığını tercih etmişlerdir. 16 konu başlı̆̆1 ve eğitim saatleri Tablo 1'de gösterilmiştir.

Tablo 1.

Proje Sürecinde Gençlerin Gerçekleşmesi Planlanan Bilimsel Etkinliklere Yönelik Görüşleri

\begin{tabular}{lll}
\hline SN & ETKİNLIKLER & SAAT \\
\hline 1 & Bilim tarihi ve Türk ve İslam dünyasında bilim âlimleri eğitimi & 26 \\
2 & İletişim eğitimi & 8 \\
3 & Takım çalı̧şması, buluşçuluk, proje fikri geliştirme eğitimi & 24 \\
4 & Kariyer planlama eğitimi & 19 \\
5 & Gençlerde çatı̧̧ma yönetimi konferansı & 6 \\
6 & Ekolojik okuryazarlık eğitimi & 6 \\
7 & Bilimsel okuryazarlık eğitimi & 8 \\
8 & Coğrafya eğitimi & 8 \\
\hline
\end{tabular}




\begin{tabular}{lll}
\hline 9 & Sağlıkta kariyer olanakları & 6 \\
10 & Bilimde alternatif yöntemler eğitimi & 8 \\
11 & Görsel tasarım kursu & 24 \\
12 & Satranç kursu & 30 \\
13 & Kariyer danışmanlığı & 52 \\
14 & Konya Bilim Merkezi çalışma ziyareti & 8 \\
15 & Hacettepe Üniversitesi Hacettepe Teknokent A.Ş ziyareti & 8 \\
16 & SOLOTÜRK ziyareti & 8 \\
\multicolumn{2}{l}{ TOPLAM } & 249 \\
\hline
\end{tabular}

Anket sonucunda elde edilen tercihler değerlendirilmiş, değerlendirme sonuçlarına göre etkinlikler, alanında uzman olan eğitimciler tarafından gerçekleştirilmiştir. Geliştirilen eğitim programlarının telif hakları Uluslararası Bilim Derneği'ne ait olduğundan programın ayrıntılarına detaylı yer verilmemiştir kısa açıklamalarla yetinilmiştir. Proje sırasında etkinlikler 15-29 yaş arası 1158 gence 15-20, 20-25 ve 25-29 yaş olmak üzere 3 grup halinde ve toplam 249 saat olarak 16 bilimsel etkinlik gerçekleştirilmiştir. Gerçekleştirilen etkinlikler;

1. Bilim tarihi ve Türk ve İslam dünyasında bilim âlimleri eğitimi: Bilim tarihi, Türk ve İslam dünyasında bilim tarihi, Türk ve İslam dünyasında bilim alimleri, İslamiyet'in bilime verdiği önem

2. Illetişim eğitimi: Beden dili, sözsüz ve sözlü iletişim, iletişim kaynakları, sunum teknikleri, stres yönetimi

3. Takım çalışması, buluşçuluk, proje fikri geliştirme eğitimi: Proje fikri geliştirme, projeleri destekleyen kurum ve kuruluşları takip etme, proje firsatlarını değerlendirme, proje konusu, projenin kapsamı, projenin içeriği ile ilgili alanyazın taraması, projenin amaçları ve hedefleri, proje faaliyetleri, bütçelendirme, başarı ölçütleri, risk yönetimi, proje ekibi, proje çıktıları, sürdürülebilirlik, çarpan etkileri, proje matrisi

4. Kariyer planlama eğitimi: Bireyin kendini tanıması, kişisel gelişim, öncelikleri belirleme, kariyer meslekleri, meslekleri tanıma, iş dünyasını tanıma, bireyin kendisine uygun meslekleri ve işleri tanıması, özgeçmiş hazırlama, iş arama, iş başvurusu, ilk görüşme, iş dünyas1

5. Gençlerde çatışma yönetimi konferansı: Zor insanlarla baş etme, baskı altında davranış modelleri, çatışma kaynakları, benzerlikler ve farklılıklar, beklentilerin karşılanmaması, çatışmaların pozitif ve negatif etkileri, hakemlik ve arabuluculuk, çatışma yönetme stilleri

6. Ekolojik okuryazarlık eğitimi: Ekolojinin temel ilkeleri, ekolojik okuryazarlığın temel ilkeleri, akıcı öğrenme, doğayla empati geliştirme

7. Bilimsel okuryazarlı eğitimi: Bilimsel bilgi, bilimsel bilginin özellikleri, bilimsel okuryazarlık kavramı, bilimsel okuryazarlığın temel ilkeleri, bilimsel okuryazarlığın bireye katkıları, topluma katkıları

8. Coğrafya eğitimi: Doğal sistemler, beşeri sistemler, doğa ve insan, doğal kaynaklar, diş kuvvetler, nüfus ve yerleşme, göç, harita okuma becerisi

9. Sağlıkta kariyer olanakları: Kariyer planlama, bireyin kendini tanıması, bireye uygun iş ortamı, sağlıkta kariyer olanakları 
10. Bilimde alternatif yöntemler eğitimi: Bilimde alternatif yöntemler nelerdir, yararları ve katkıları, tercih edilebilirliği, kullanım alanları

11. Görsel tasarım kursu: Görsel tasarım kavramı, ilkeleri, öğeleri, tasarımın oluşumu, tasarımın dalları, tasarım süreci, tasarımın görselleştirilmesi, görsel tasarımın oluşturulması

12. Satranç kursu

13. Kariyer danışmanlığı kapsamında

14. Konya Bilim Merkezi çalışma ziyareti

15. Hacettepe Üniversitesi Hacettepe Teknokent A.Ş ziyareti

16. SOLOTÜRK ziyareti

Projenin bitiminden sonraki Eylül 2015- Haziran 2017 döneminde 800 öğrenciye toplam 172 saat olarak teknoloji okuryazarlığı, madde bağımlılığı, teknoloji bağımlılı̆̆ı, ihmal ve istismarın önlemesi, kadına şiddetin önlenmesi, proje hazırlama, Türk İslam Bilim İnsanları, bilimsel araştırma yöntem ve teknikleri, bilimsel okuryazarlık, medya okuryazarlı̆ğ, yaşlılarımıza ve büyüklerimize destek olma, değerler eğitimi, Türk Dış Politikası, Türkiye AB İlişkileri, Türkiye Ortadoğu İlişkileri konularında atölye çalışmaları gerçekleştirilmiştir. Çalışma boyunca Eylül 2014-Eylül 2015 döneminde 249 saat ve Eylül 2015- Haziran 2017 döneminde atölye çalışmalarında 172 olmak üzere 421 saat etkinlik gerçekleştirilmiştir.

Gençlerin katıldıkları bilimsel etkinliklere yönelik değerlendirmelerine ilişkin bulgular Gençlerin katıldıkları bilimsel etkinliklere yönelik değerlendirmeleri "Bilimsel Etkinlikleri Değerlendirme Anketi" ve "Bilimsel Etkinlikleri Değerlendirme Görüşme Formu" ile ölçülmüştür. Gençlerin katıldıkları bilimsel etkinliklerden memnuniyetleri Tablo 2'de gösterilmiştir.

Tablo 2.

Gençlerin Katıldıkları Bilimsel Etkinliklerden Memnuniyetleri

\begin{tabular}{|c|c|c|c|c|c|}
\hline & Etkinlik & 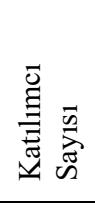 & 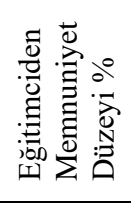 & 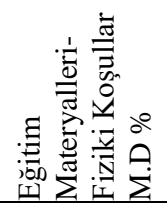 & 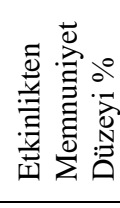 \\
\hline 1 & $\begin{array}{l}\text { Bilim tarihi ve Türk ve İslam dünyasında bilim âlimleri } \\
\text { eğitimi }\end{array}$ & 50 & 86 & 89 & 87 \\
\hline 2 & İletişim eğitimi & 75 & 85 & 90 & 89 \\
\hline 3 & $\begin{array}{l}\text { Takım çalışması, buluşçuluk, proje fikri geliştirme } \\
\text { eğitimi }\end{array}$ & 80 & 87 & 89 & 88 \\
\hline 4 & Kariyer planlama eğitimi & 120 & 88 & 88 & 89 \\
\hline 5 & Gençlerde çatışma yönetimi konferansı & 152 & 85 & 92 & 92 \\
\hline 6 & Ekolojik okuryazarlık eğitimi & 43 & 89 & 90 & 87 \\
\hline 7 & Bilimsel okuryazarlık eğitimi & 32 & 86 & 91 & 88 \\
\hline 8 & Coğrafya eğitimi & 26 & 89 & 90 & 90 \\
\hline 9 & Sağlıkta kariyer olanakları eğitimi & 23 & 86 & 89 & 94 \\
\hline 10 & Bilimde alternatif yöntemler eğitimi & 98 & 92 & 94 & 96 \\
\hline 11 & Görsel tasarım kursu & 24 & 90 & 90 & 90 \\
\hline 12 & Satranç kursu & 20 & 88 & 90 & 90 \\
\hline 13 & Kariyer danışmanlığ 1 & 134 & 90 & 92 & 92 \\
\hline 14 & Konya Bilim Merkezi çalışma ziyareti & 5 & 94 & 98 & 98 \\
\hline 15 & $\begin{array}{l}\text { Hacettepe Üniversitesi Hacettepe Teknokent A.Ş } \\
\text { ziyareti }\end{array}$ & 134 & 96 & 96 & 96 \\
\hline 16 & SOLOTÜRK ziyareti & 142 & 96 & 98 & 98 \\
\hline & Toplam & 1158 & 89.19 & 91.63 & 89.87 \\
\hline 17 & Atölye çalışmaları & 800 & 92 & 94 & 94 \\
\hline & Toplam & 800 & 92 & 94 & 94 \\
\hline \multicolumn{2}{|c|}{ Genel Toplam } & 1958 & 90.59 & 92.81 & 91.93 \\
\hline
\end{tabular}


Tablo 2'ye göre bilimsel etkinliklere toplam 1158 genç katılmıştır. Gençlerin eğitimciden memnuniyet düzeyleri ortalama $\% 89.19$, eğitim materyalleri ve fiziki koşullardan memnuniyet düzeyleri \%91.63, genel memnuniyet düzeyleri ise \%89.87 olarak ölçülmüştür. Gençlerin SOLOTÜRK ziyareti ve Konya Bilim Merkezi Çalışma Ziyareti etkinliklerinden yüksek düzeyde memnun kaldıkları \%98 görülmektedir. Gençlerin eğitimciden, eğitim materyalleri ve fiziki koşullardan memnuniyetlerinin ve genel memnuniyet düzeylerinin yüksek olmasının Uluslararası Gençlik ve Bilim Merkezi'nin kuruluş amacına hizmet ettiğinin ve yapılan etkinliklerin bu anlamda başarılı olduğunun göstergesi olması bakımında memnun edicidir.

Bilimsel etkinliklere katılan 15 genç ile yüz yüze görüşmeler yapılmış ve katıldıkları etkinlikleri fiziki olanaklar ve eğitim materyalleri, eğitimci ve proje açılarından değerlendirmeleri istenmiştir. Katılımcıların görüşleri ise şöyledir.

\section{Gençlerin fiziki olanaklar ve eğitim materyallerine iliş̧kin görüşleri}

Görüşme yapılan 15 gencin \%80'i bilimsel etkinliklerin gerçekleşmesi sırasında fiziki olanaklar ve eğitim materyallerinin yeterli olduğunu düşündüklerini, \%20si ise kararsız olduklarını belirtmiş̧lerdir. Ayrıca gençlerin \%90'ı eğitim sırasında yapılan ikramlar ve promosyonlardan memnuniyetlerini dile getirirken $\% 10$ 'u ise ikram ve promosyonların daha fazla olabileceğini düşündüklerini ifade etmişlerdir.

\section{Gençlerin eğitimcilere ilişkin görüşleri}

Görüşme yapılan 15 gencin \%93,3'ünün bilimsel etkinlikleri gerçekleştiren eğitimcilerin anlattıkları konularda yeterli olduğunu düşündüklerini, \%6,7'si ise bu konuda kararsız olduklarını ifade etmişlerdir. 15 gencin $\% 73,3$ 'ünün bilimsel etkinlikleri gerçekleştiren eğitimcilerin kariyerlerine ve kişisel gelişimlerine katkı sağladıklarını ifade ederken \%26.7'si ise bilimsel etkinliklerin katkılarının ve etkilerinin uzun vadede daha net ortaya çıkacağını düşündüklerini ifade etmişlerdir.

\section{Gençlerin projenin yaşamlarına katkısına iliş̧kin görüşleri}

Görüşülen gençlerin \%86,7'si projenin okul yaşamlarına olumlu katkısı olduğunu, özellikle katıldıkları bilimsel etkinliklerin okul başarılarını arttırdığını ifade ederken $\% 13,3$ 'ü ise projenin okul yaşamlarına katkılarını uzun vadede göreceklerine inandıklarını ifade etmişlerdir. Gençlerin \% 53,3'ü katıldıkları etkinliklerin bireysel gelişimlerine olumlu katkılar sağladığını \%33,3'ü kariyer planlama konusunda önemli katkılar sağladığını, \%13,4'ü ise bilime yönelik algılarında olumlu yönde değişim olduğunu ifade etmişlerdir.

\section{Gençlerin projeye ilişkin görüşleri}

Gençlerin tamamı projeyi beğendiklerini, Türkiye'de Bilim Merkezlerinin açılmasının gençler için olumlu olduğunu ifade etmişlerdir. Gençlerin \%73.3'ü ise var olan gençlik merkezlerinin etkinliklerinin arttırılması gerektiğini, \%26,7'si okul dışında çalışmak zorunda olduğundan, gençlik merkezlerinin faaliyetlerinin kendisi için yeterli olduğunu ifade etmişlerdir. Gençlerin \%86.7'si bilimi sevdiren etkinliklerin artmasının gençler için çok iyi olduğunu ifade ederken, $\% 13,3$ 'ü bilimsel etkinliklerin yeterli olduğunu ifade etmişlerdir.

\section{Gençlerin projenin sürdürülebilirliğine ilişkin görüşleri}

Görüşme yapılan 15 gencin tamamı Uluslararası Gençlik ve Bilim Merkezi'ndeki çalışmalardan faydalandıklarını, ülkemizdeki bilim merkezlerinin artmasının gençlere faydalı olacağını düşündüklerini, çalışmanın devam etmesini istediklerini, benzeri projelere katılmayı her zaman isteyeceklerini, projenin hem kişisel gelişimlerine hem de akademik hayatlarına olumlu katkıları olduğunu ifade etmişlerdir. Görüşme yapılan gençlerin \%93.3'ü merkezde yapılan faaliyetlere proje bittikten sonra da devam etmek istediğini \%6.7'si ise yabanc1 öğrenci olduğundan ülkesine döneceğinden katılamayacağını ifade etmiştir. 
Gençlerin atölye çalışmalarına ilişkin görüşleri

Görüşme yapılan 22 gencin tamamı atölye çalışmalarından çok memnun kaldıklarını, projenin çok faydalı olduğunu, gençlere bilimi sevdirmek ve bilimle ilgilenmelerini sağlamak adına özendirici olduğunu, bilim merkezlerinin sayılarının artması gerektiğini, atölye çalışmalarından çok faydalandıklarını, devam ederse kesinlikle katılmaya devam edeceklerini ifade etmişlerdir.

\section{Tartışma, Sonuç ve Öneriler}

Uluslararası Gençlik ve Bilim Merkezi ülkemizde bir sivil toplum kuruluşu tarafından kurulan ve yürütülen ilk gençlik merkezi olma özelliğini taşımasının yanında kurulumunun proje destek programı kapsamında gerçekleşmesi anlamında örnek teşkil etmektedir. Proje bitmesine rağmen 800 gence atölye çalışmaları şeklinde ulaşılmış, derneğin imkânları çerçevesinde merkez açık tutulmuş bilimi sevdirme programı uygulanmış, Türk İslam bilim insanları tanıtılmıştır. Yaş gruplarına göre bilim dersi onlara özel hazırlanmıştır. Çalışma bitiminde isteyen okullara ve öğretmenlerine malzemeler değişik okullara bilimi geliştirmek için hibe edilmiştir.

Araştırma sonucunda gençlerin bilimsel etkinliklerden genel memnuniyet düzeyinin, eğitimciden memnuniyet düzeyinin ve fiziki olanaklar ve eğitim materyallerinden memnuniyet düzeyinin oldukça yüksek olduğu görülmüştür. Gençler eğitim sırasında yapılan ikramlar ve promosyonlardan memnuniyetlerini dile getirmişlerdir. Ayrıca bilimsel etkinlikleri gerçekleştiren eğitimcilerin anlattıkları konularda yeterli olduğunu, bilimsel etkinlikleri gerçekleştiren eğitimcilerin kariyerlerine ve kişisel gelişimlerine katkı sağladıklarını ifade etmişlerdir. Gençlerin ilgilerini çeken yöntem ve tekniklerle bilim anlatıldığında gençlerin bilime olan olumlu bakış açılarının arttığı söylenebilir. Kaldı ki Öztürk ve Başbay (2017) tarafından yapılan Mevlana Toplum ve Bilim Merkezi öğretim programlarının öğrencilerin bilimsel süreç becerilerine ve bilime yönelik tutumlarına etkisi konulu çalışmada elde edilen bu bulgulara göre, geliştirilen Öğretim Programının, öğrencilerin bilimsel süreç becerilerini geliştirmede etkili olduğu fakat bilimsel tutumlarını geliştirmede yeteri kadar etkili olmadığ 1 sonucuna ulaşılmıştır.

Görüşülen gençlerin \%86,7'si projenin okul yaşamlarına olumlu katkısı olduğunu, özellikle katıldıkları bilimsel etkinliklerin okul başarılarını arttırdığını ifade ederken \%13,3ü ise projenin okul yaşamlarına katkılarını uzun vadede göreceklerine inandıklarını ifade etmişlerdir. Gençlerin tamamı projeyi beğendiklerini, Türkiye'de Bilim Merkezlerinin açılmasının gençler için olumlu olduğunu ifade etmişlerdir. Gençlerin \%73.3'ü ise var olan gençlik merkezlerinin etkinliklerinin arttırılması gerektiğini, \%26,7'si okul dışında çalışmak zorunda olduğundan, gençlik merkezlerinin faaliyetlerinin kendisi için yeterli olduğunu ifade etmişlerdir. Gençlerin \%86.7'si bilimi sevdiren etkinliklerin artmasının gençler için çok iyi olduğunu ifade ederken, $\% 13,3$ 'ü bilimsel etkinliklerin yeterli olduğunu ifade etmişlerdir.

Sonuç olarak, Uluslararası Gençlik ve Bilim Merkezi'nin kurulması ve faaliyete geçmesine yönelik projenin ve proje kapsamında yapılan araştırmanın amacına hizmet ettiği söylenebilir. Proje sırasında gerçekleştirilen faaliyetlerin bir kısmı dernekte hala devam etmektedir. Gençlerin talepleri, önerileri ve geribildirimleri doğrultusunda yeni bilimsel etkinlikler de yürütülmektedir. Türkiye nüfusunun $\% 25$ 'ini oluşturan gençlerin bilimi sevmesi ve bilime hizmet etmesi geleceğimizin şekillenmesinde son derece önemlidir, gençlere yönelik çalışmaların artması da bu anlamda faydalı olacaktır. Gençlik ve Spor Bakanlığı'nın bu projeye verdiği destek gibi benzer projelere olan desteklerin sürdürülmesi, benzer çalışmaların artmasını kolaylaştıracaktır. Uluslararası Gençlik ve Bilim Merkezi gerek kuruluş aşaması gerekse alanında yaptığı faaliyetler ile ülkemizde örnek ve önder olması bakımından son derece önemli ve etkili bir noktadadır.

\section{Teşekkür}

Bu çalışma Eylül 2014-2015 döneminde Şuay Nilhan Açıkalın koordinatörlüğünde yürütülen 2014 Yılı Gençlik Projeleri Destek Programı I. Çağrı Döneminde TC Gençlik ve Spor Bakanlığı tarafından desteklenen "Uluslararası Gençlik ve Bilim Merkezi" Projesi kapsamında gerçekleştirilmiştir. TC Gençlik ve Spor Bakanlığı’na teşekkür ederiz. 


\section{Kaynaklar}

Aydın, H. (2002). İslam dünyasında bilim ve felsefe: Yükseliş ve duraklama. Bilim ve Ütopya Dergisi, 94-95.

Beetlestone, J. G., Johnson, C. H., Quin, M. ve White, H. (1998). The science center movement: Contexts, practice, next challenges. Public Understand Science, 5-26. https://doi.org $/ 10.1177 / 096366259800700101$

Buluş Kırıkkaya, E. (2010). Lise öğrencilerinin bilime ve bilim insanlarına karşı ilgi ve yöneliminde fen dersleri ve fen öğretmenlerinin rolü. Kastamonu Ĕ̆itim Dergisi, 18(1), 99-114.

Eberle, F. Q. (2011, May/June). The role of science centers in professional development. E. Schuster (Yay. haz.). ASTC Dimensions içinde (s. 19). Association of ScienceTechnology Centers Incorporated. Washington DC, U.S.A.

Dosay, M. (1992). İslâm dünyasında bîr bilim rönesansı ihtiyacı ve koşulları. Ankara Üniversitesi Dil ve Tarih Coğrafya Fakültesi Dergisi, 35(1), 75-80.

Falk, J. H., Needham, M. D., Dierking, L. D. ve Prendergast, L. (2014). International science centre impact study final report. The International Science Centre, Corvallis, USA

Fernandes Sousa, A. I. (2017, May). Exhibit development in a science centre. Internship Report. Internship at Glasgow Science Centre, Glasgow, UK.

Fors, V. (2006). The missing link in learning in science centres. (Unpublished doctoral thesis). Department of Educational Sciences, Luleå University of Technology, Luleå, Sweden.

Garnett, R. ve Ghislaberti, A. (2001). The impact of science centers/museums on their surrounding communities: Summary report. Questacon - The National Science and Technology which is located in Canberra, Australia.

Kaya, V. H., Afacan, Ö., Polat, D. ve Urtekin, A. (2013). İlköğretim öğrencilerinin bilim insanı ve bilimsel bilgi hakkındaki görüşleri (Kırşehir İli örneği). Ahi Evran Üniversitesi Kırşehir Eğitim Fakültesi Dergisi (KEFAD), 14(1), 305-325.

Kaya, G. ve Yılmaz, S. (2016). Açık sorgulamaya dayalı öğrenmenin öğrencilerin başarısına ve bilimsel süreç becerilerinin gelişimine etkisi. Hacettepe Üniversitesi Eğitim Fakültesi Dergisi, 31(2), 300-318.

Öztürk, A. ve Başbay, A. (2017). Mevlana Toplum ve Bilim Merkezi Öğretim Programlarının Öğrencilerin Bilimsel Süreç Becerilerine ve Bilime Yönelik Tutumlarına Etkisi. Kastamonu Eğitim Dergisi, 25(1), 283-298.

Segal, A. (2015). Islam dünyası bilimde neden geri kaldı? C. Öney. (Çev.). Journal of History and Future, 1(1), 172-203.

Sezgin, F. (2007). İslam'da bilim ve teknik, Cilt I: Arap - İslam bilimleri tarihine giriş. Ankara: Kültür ve Turizm Bakanlığı, Türkiye Bilimler Akademisi, İstanbul Büyükşehir Belediyesi Kültür A. Ş. Yayınları.

TUBITTAK (2005). Bilim okuryazarlı̆̆ı araştırması. Ankara: Türkiye Bilimsel ve Teknolojik Araştırma Kurumu.

Türkiye İstatistik Kurumu Nüfus İstatistikleri Erişim adresi: www.tuik.gov.tr

Ucko, D. A. (2013). Science centers in a new world of learning. Curator, 56(1), 21-30.

\section{Extended Abstract}

\section{Introduction}

This study was conducted within the context of "International Youth and Science Center" Project by the International Science Association, coordinated by Şuay Nilhan Açıkalın during September 2014-2015 period. Project was sponsored by the Turkish Ministry of Youth and Sports during the 1. Call Period of the 2014 Youth Projects Support Program. The purpose of the study is to explain the establishment of the International Youth and Science Center which was established with the aim of explaining love of science to young people and integrating them to science with activities through the scope of the project. 


\section{Method}

The research was designed in survey model and a multi-method strategy was used. 1158 young people whose ages were 15-29, including 570 girls and 588 boys, participated in the study. After the project was completed, activities within the project in the form of workshops were held until June 2017 with its own resources of the International Science Association., 800 young people, 420 girls and 380 boys whose ages were 15 and 29 participated in the workshops during the September 2015-June 2017 period. In total, 1958 young people, 990 girls and 968 males, participated in the study. Sixteen scientific activities as 172 hours were carried out to three groups (15-20, 20-25 and 25-29 years of age) for each activity. In the continuation of the project, 249 hours of workshops were carried out. "Views of Youths on Regarding the Scientific Planned Activities Questionnaire", Scientific Activities Evaluation Questionnaire" and "Scientific Activities Evaluation Interview Form" developed by the researchers were used as data collection tools.

Descriptive statistical methods were used to determine the opinions of the youth about the scientific activities planned for the 15-29 year olds who live in Ankara and continue to the International Center for Youth and Science. The data on the opinions of the young people about the scientific activities they participated in were gathered by conducting individual interviews and analyzed the content in the analysis and interpretation.

\section{Result and Discussion}

According to the preferences of the young people, these activities were realized; the researches of science history and Islamic Scientist in Islamic World, effective communication, team work, invention, project idea development, career planning education, research methods and techniques, research ethics, the conflict management conference for young people, ecological literacy education, scientific literacy education, geography, career opportunities in health, alternative methods education in science, visual design course, chess course, career counseling, Konya Science Center study visit, Hacettepe University Hacettepe Technopolis Inc. visit, SOLOTÜRK visit.

As a result of the research, it was seen that the level of general satisfaction level of young people on scientific activities, trainers, physical conditions and educational materials were high. They also stated that the trainers who performed the scientific activities were expert in the topics, and they said that these activities contribute to their careers and also personal development.

$86.7 \%$ of interviewed young people said that the project contributed positively to their school life, especially the scientific activities they attended stated that they increased school achievement, while $13.3 \%$ stated that they believed that the project would contribute to the school life in the long run. Like all young people project said that it is positive for the youth of the opening of the Science Centers in Turkey. $73.3 \%$ of the youth stated that the activities of the existing youth centers should be increased and $86.7 \%$ of the youth stated that it is very good for the young people to increase the activities that like science.

Despite the completion of the project, workshops were held with 800 young people, International Science Association- International Youth and Science Center was opened in the framework of the possibilities of the association, a program of love of science was implemented and Turkish Islamic scientists were introduced. Science lessons are specially prepared depend on age groups. At the end of the study, materials to schools and teachers who requested were donated to improve their facilities.

Turkey is extremely important in shaping our future to serve youth, the love of science and science $25 \%$ of the population, further studies would be useful in this respect to young people. The International Youth and Science Center is an extremely important and effective place in terms of being both an institutional stage and an example and leader in our country with its activities in the field. 


\section{Acknowledgements}

"International Youth and Science Center" Project was sponsored by the Turkish Ministry of Youth and Sports during the 1. Call Period of the 2014 Youth Projects Support Program and was conducted by the International Science Association, coordinated by Şuay Nilhan Açıkalın during September 2014-2015 period. We thank to Turkish Ministry of Youth and Sports. 